\title{
ANALISIS IMPLEMENTASI PROGRAM JAMINAN KESEHATAN NASIONAL BERDASARKAN ANGGOTA KEPESERTAAN BPJS (STUDI DI PUSKESMAS WIYUNG, KOTA SURABAYA TAHUN 2017)
}

\author{
Satriya Wijaya \\ Fakultas Kesehatan, Universitas Nahdlatul Ulama Surabaya \\ email: swijaya7@unusa.ac.id or swijaya7@gmail.com
}

\begin{abstract}
Abstrak
Pelaksanaan JKN di Indonesia menghadapi berbagai tantangan, dari sisi pemberi layanan kesehatan, pengelola jaminan kesehatan, masyarakat sebagai pengguna, serta pemerintah sebagai regulator program. Berbagai studi telah dilakukan untuk menelaah dampak JKN pada pelayanan kesehatan di Indonesia, namun pemanfaatan hasil studi tersebut untuk menyempurnakan kebijakan masih terbatas. Jenis penelitian ini adalah penelitian deskriptif eksploratif, yang menggunakan metode deskriptif kualitatif serta penelaahan dokumen. Desain penelitian adalah cross-sectional dengan pendekatan retrospektif. Sampel penelitian ini adalah seluruh stakeholder kunci yang berada di wilayah kerja Puskesmas Wiyung yang terkait erat dengan pelaksanaan JKN. Analisa dan pengumpulan data dilakukan untuk memvalidasi: informasi dari institusi responden, indepth interview dengan stake holder kebijakan dan pelaksana program, kemudian cek silang oleh enumerator lapangan ke beberapa responden untuk temuan yang memerlukan, dan refleksi tim dalam bentuk pertemuan validasi data. Informasi yang diperoleh dari hasil indepth interview stake holder kebijakan dan pelaksana program, informasi cek silang dari enumerator lapangan maupun data sekunder akan diintegrasikan dengan informasi kualitatif yang terkumpul. Hasil analisis menunjukkan tidak semua pengunjung Puskesmas Wiyung telah menjadi peserta BPJS. Sistem administrasi dianggap rumit untuk dipahami dengan mudah oleh masyarakat. Perlu sosialisasi kepada masyarakat tentang kepesertaan BPJS dan penguatan koordinasi dengan pihak BPJS apabila ada masalah anggota kepesertaan pasien BPJS.
\end{abstract}

Kata kunci: implementasi JKN, program JKN, kepesertaan BPJS

\begin{abstract}
Implementation of National Health Insurance $(J K N)$ in Indonesia faces various challenges, from the side of health care providers, health insurance managers, the community as users, and the government as the program regulator. Various studies have been conducted to examine the impact of JKN on health services in Indonesia, but the use of the results of these studies to improve policies is still limited. This type of research is explorative descriptive research, which uses qualitative descriptive methods and document review. The study design was cross-sectional with a retrospective approach. The sample of this study is all key stakeholders in the Wiyung Health Center working area which are closely related to JKN implementation. Analysis and data collection were carried out to validate: information from the respondent's institution, indepth interviews with policy stakeholders and program implementers, then cross-check by field enumerators to several respondents for findings that needed, and team reflection in the form of data validation meetings. Information obtained from the results of an in-depth interview of policy stakeholders and program implementers, cross check information from field enumerators and secondary data will be integrated with qualitative information collected. The results of the analysis showed that not all visitors to the Wiyung Health Center had become BPJS participants. The administrative system is considered complicated to be easily understood by the community. Need to disseminate information to the public about BPJS membership and strengthening coordination with BPJS if there are problems with membership of BPJS patients.
\end{abstract}

Keywords: implementation of JKN, JKN program, BPJS membership 


\section{PENDAHULUAN}

Program Jaminan Kesehatan Nasional yang diluncurkan pada awal 2014 merupakan program jaminan perlindungan kesehatan secara komprehensif meliputi layanan promotif, kuratif, serta rehabilitatif yang ditujukan untuk seluruh rakyat Indonesia. Tujuan utama dari jaminan kesehatan ini adalah agar peserta memperoleh manfaat pemeliharaan kesehatan dan perlindungan dalam memenuhi kebutuhan dasar kesehatan dengan cara meningkatkan akses dan mutu pelayanan kesehatan (Depkes RI, 2004).

Seiring dengan implementasi dari program ini, seperti halnya program atau inisiatif lainnya yang baru berjalan, berbagai tantangan muncul dan membutuhkan penanganan segera. Salah satu tantangan ini berkaitan dengan berbagai regulasi atau peraturan terkait JKN yang muncul di level nasional, provinsi dan juga kabupaten/kota. Regulasi yang kompleks tentang JKN memiliki potensi tantangan dalam interpretasi, kesiapan pelaksanaannya sendiri, serta sinkronisasi dengan aturan lainnya, termasuk regulasi tentang layanan primer dan sekunder yang sudah ada sebelumnya. Regulasi baru ini dapat mempengaruhi implementasi di lapangan. Tantangan lain adalah kesiapan daerah di Indonesia yang sangat beragam, dimana terdapat kabupaten/kota yang telah siap untuk mengelola program JKN dan di sisi lain cukup banyak daerah yang belum memiliki infrastruktur serta sistem pengelolaan yang memadai. Hal ini juga berhubungan dengan situasi internal di daerah tersebut dan situasi eksternal yang juga mempengaruhi implementasi kebijakan.

Tantangan dalam aspek regulasi dan kesiapan ini juga secara khusus ada di level pelayanan kesehatan primer karena layanan primer merupakan kunci awal dari keberhasilan JKN dalam menjaga kesehatan populasi secara komprehensif. Tanpa pencapaian target di layanan primer, maka tujuan utama JKN tidak akan berhasil. Oleh karena itu, setelah dua tahun implementasi JKN, aspek-aspek yang menjadi potensi tantangan ini perlu segera ditelaah melalui studi sistematis mengenai pelaksanaan kebijakan dan kesiapan di berbagai daerah yang memiliki lingkungan yang berbeda-beda.

Program Jaminan Kesehatan Nasional yang diresmikan pada tanggal 1 Januari 2014 ini dilaksanakan serentak di seluruh Puskesmas dan Rumah Sakit di Indonesia yang dilembagai oleh BPJS. Dalam program Jaminan Kesehatan Nasional (JKN), pemberian Bantuan Iuran (PBI) tidak terlepas dari masalah atau kendala dalam pelaksanaannya, beberapa masalah atau kendala yang dihadapi, menurut Hubaib Alif Khariza yang melakukan penelitian pada bulan Januari-April tahun 2015 mendeskripsikan permasalahan yang ada pada pelaksanaan Jaminan Kesehatan Nasional $(\mathrm{JKN})$ yaitu:

Tabel 1. Deskripsi dan Permasalahan dalam JKN

\begin{tabular}{|c|c|}
\hline Permasalahan & Deskripsi \\
\hline Sosialisasi & $\begin{array}{l}\text { Masih banyak masyarakat yang belum } \\
\text { mengetahui prosedur jaminan } \\
\text { kesehatan Fasilitas Kesehatan }\end{array}$ \\
\hline $\begin{array}{l}\text { Fasilitas } \\
\text { Kesehatan }\end{array}$ & $\begin{array}{l}\text { a. Pelayanan Puskesmas dan Klinik } \\
\text { yang ditunjuk sebagai penyedia } \\
\text { JKN belum memadai; }\end{array}$ \\
\hline & $\begin{array}{l}\text { b. Fasilitas banyak yang belum } \\
\text { memenuhi standar; } \\
\text { c. Jumlah dokter terhadap pasien } \\
\text { masih kurang ideal }\end{array}$ \\
\hline Kesediaan & $\begin{array}{l}\text { a. Masih ada kekhawatiran Rumah } \\
\text { Sakit jika BPJS tidak akan }\end{array}$ \\
\hline Data & $\begin{array}{l}\text { membayar tunggakan dari pasien; } \\
\text { b. Masih ada keraguan tentang } \\
\text { keamanan sistem data peserta BPJS }\end{array}$ \\
\hline
\end{tabular}

Tujuan penelitian ini menghasilkan masukan untuk perbaikan kebijakan dan implementasi program JKN yang tepat melalui fokus di layanan primer untuk mendukung pencapaian program JKN itu sendiri. Berdasarkan uraian dari latar belakang diatas, untuk meninjau proses implementasi kebijakan Program Jaminan Kesehatan Nasional, maka peneliti menggunakan teori dari George C. Edward III dalam buku Widodo (2013) yang meliputi Komunikasi, Sumberdaya, Disposisi, dan Struktur Birokrasi dalam implementasi Jaminan Kesehatan Nasional di Puskesmas Wiyung. Dengan teori yang dikemukakan oleh George C. Edward III dapat memberi gambaran tentang Jaminan Kesehatan Nasional dengan jelas baik dari faktor pendukung maupun penghambatnya.

\section{METODE PENELITIAN}

Jenis penelitian ini adalah penelitian deskriptif eksploratif. Penelitian ini menggunakan metode deskriptif kuantitatif dan kualitatif serta penelaahan dokumen. Desain penelitian adalah cross-sectional dengan pendekatan retrospektif.

Sampel pada penelitian ini menggunakan sampel jenuh, yang artinya sampel merupakan keseluruhan populasi yang ada. Sehingga sampel pada penelitian ini adalah seluruh stakeholder 
kunci yang berada di wilayah kerja Puskesmas Wiyung dan yang terkait erat dengan pelaksanaan JKN.

Sedangkan variabel yang diukur maupun diamati dalam penelitian ini adalah akseptabilitas, adopsi, ketepatan, kelayakan dan kepatuhan.

Pengumpulan data dilakukan dengan indepth interview dengan masing-masing personal dalam institusi Puskesmas. Selama pengumpulan data, beberapa langkah berikut dilakukan untuk memvalidasi: informasi dari institusi responden, melakukan indepth interview dengan stake holder kebijakan dan pelaksana program kemudian cek silang oleh enumerator lapangan ke beberapa responden untuk temuan yang memerlukan, dan refleksi tim dalam bentuk pertemuan validasi data. Validasi data dilakukan dalam forum diskusi di mana enumerator, dan tim peneliti akan mendiskusikan hasil pengumpulan data di lapangan. Informasi yang diperoleh dari hasil indepth interview stake holder kebijakan dan pelaksana program, informasi cek silang dari enumerator lapangan maupun data sekunder akan diintegrasikan dengan informasi kualitatif yang terkumpul. Integrasi ini dilakukan untuk memperoleh hasil yang lebih komprehensif.

\section{HASIL DAN PEMBAHASAN}

\section{Gambaran Outcome Implementasi Program JKN di Puskesmas Wiyung Berdasarkan Variabel Akseptabilitas}

Gambaran outcome implementasi program JKN di Puskesmas Wiyung berdasarkan variabel akseptabilitas dapat diketahui bahwasanya pengembangan kebijakan mengenai JKN tidak dapat dilakukan karena semua prosedur dan pembiayaan sudah diatur sedemikian rupa oleh pembuat kebijakan, sehingga pihak pemberi layanan hanya bisa menjalankan segala prosedur sesuai dengan peraturan perundang-undangan yang berlaku. Namun hal itu tidak menjadi penghalang dalam pelaksanaannya, karena pihak pemberi pelayanan mampu memenuhi segala prosedur yang telah ditetapkan.

Biaya yang dibayarkan BPJS kepada Puskesmaspun juga telah dipatok jumlah dan peruntukannya. Misalnya untuk biaya promosi kesehatan, biaya obat-obatan, dan lain sebagainya. Puskesmas hanya bertugas menjalankan dan memanfaatkan uang yang sudah diberikan dengan sebaik-baiknya.

\section{Gambaran Outcome Implementasi Program JKN di Puskesmas Wiyung Berdasarkan Variabel Adopsi}

Berdasarkan variabel adopsi sejauh ini Puskesmas Wiyung selalu menyesuaikan semua prosedur pelayanan terkait JKN dengan peraturan yang ada, karena memang tidak boleh menyimpang dari kebijakan yang telah ditentukan. Dan bila ada rencana untuk menyesuaikan apabila ada perubahan regulasi atau kebijakan dari BPJS, pihak Puskesmas Wiyung hanya bisa menyesuaikan sesuai kebijakan yang dikeluarkan oleh Pemerintah. Namun tidak ada rencana sebelumnya untuk itu, karena Puskesmas tidak bisa memprediksi perubahan tentang kebijakan BPJS.

\section{Gambaran Outcome Implementasi Program JKN di Puskesmas Wiyung Berdasarkan Variabel Ketepatan}

Berdasarkan ketepatannya, program JKN di Puskesmas Wiyung telah sesuai dengan tujuan penyelenggaraan JKN yang terdapat dalam UU No. 40 Tahun 2004 Pasal 19 ayat 2 yakni menjamin peserta memperoleh manfaat pemeliharaan kesehatan dan perlindungan dalam memenuhi kebutuhan dasar kesehatan. Tujuan program JKN yaitu agar semua penduduk terlindungi dalam sistem asuransi, sehingga mereka dapat memenuhi kebutuhan dasar kesehatan masyarakat yang layak. Salah satu contoh program Puskesmas yang telah dilakukan yaitu CHN yang bertujuan untuk mengunjungi rumah terhadap populasi yang rentan dan belum terakses oleh Puskesmas. Sasaran kunjungan rumah oleh Puskesmas diantaranya penderita kanker stadium akhir, pasien gangguan jiwa dan pasien yang kurang disiplin dalam menjalani pengobatan seperti penderita TB yang tidak rutin ke Puskesmas (Jamkes Indonesia, 2017).

\section{Gambaran Outcome Implementasi Program JKN di Puskesmas Wiyung Berdasarkan Variabel Kelayakan}

Terkait outcome implementasi variabel kelayakan program JKN di Puskesmas Wiyung masih kurang begitu baik, tepatnya pada sistem pembiayaan dan pembayaran. Hal ini disebabkan karena lebih banyaknya jumlah pengunjung daripada jumlah kepesertaan BPJS. Puskesmas Wiyung sudah berupaya semaksimal mungkin untuk mengatur dan memanfaatkan dengan baik biaya kebutuhan pelayanan yang diberikan oleh Pemerintah. Namun terkadang biaya kebutuhan pelayanan yang diberikan oleh Pemerintah kurang 
sesuai seperti penyediaan obat-obatan karena jumlah pengunjung yang melonjak. Selain itu pemesanan obat dilakukan menggunakan EKatalog yang dirasa menjadi salah satu penghambat, karena terkadang terjadi keterlambatan pengiriman obat-obatan.

\section{Gambaran Outcome Implementasi Program JKN di Puskesmas Wiyung Berdasarkan Variabel Kepatuhan}

Dalam menjalankan Program JKN, Puskesmas Wiyung secara keseluruhan telah menjalankan sesuai dengan kebijakan yang diberikan oleh Pemerintah. Puskesmas mengatur biaya pelayanan yang didapat sedemikian rupa agar cukup sesuai yang dibutuhkan untuk melaksakan program JKN. Meskipun pada kenyataannya jumlah biaya yang diberikan tersebut tidak sesuai misal pada biaya pengadaan obatobatan. Namun, Puskesmas Wiyung tetap melaksanakan sesuai dengan kebijakan. Adapun biaya pelayanan dibagi menjadi $60 \%$ untuk jasa pelayanan, $40 \%$ untuk promosi kesehatan, laboratorium, obat-obatan dan ATK.

Gambaran Implementasi Program JKN di Puskesmas Wiyung Berdasarkan Kepesertaan BPJS

Terkait kepesertaan BPJS, tidak semua pengunjung Puskesmas Wiyung telah menjadi peserta BPJS. Pasalnya sistem administrasi dianggap terlalu rumit untuk dipahami dengan mudah oleh masyarakat. Dalam hal ini perlunya sosialisasi atau pemberian informasi pada masyarakat tentang kepesertaan BPJS oleh pihak BPJS. Sosialisasi yang sudah dilakukan pun hendaknya dilakukan pada beberapa kondisi dan waktu lain agar masyarakat perlahan dapat mengerti. Pemberian informasi ini juga perlu dijelaskan dengan cara yang mudah dimengerti oleh masyarakat.

\section{Hasil Identifikasi Dampak dari Pelaksanaan Kebijakan JKN pada Pelaksanaan Program di Fasilitas Kesehatan}

Kebijakan yang dibuat oleh Pemerintah Pusat mengenai Program JKN di Fasilitas Kesehatan berbeda dengan kebijakan yang dibuat oleh Pemerintah Daerah. Kebijakan Pemerintah Pusat didapatkan kurang spesifik, seperti mengenai biaya yang diberikan untuk program JKN ini tidak terperinci kegunaannya. Maka dari itu Pemerintah Daerah membuat kebijakan lebih rinci untuk Fasilitas Kesehatan yang ada di daerahnya.
Kebijakan seperti ini dirasa tidak merata karena kebijakan satu daerah dengan daerah lainnya relatif berbeda. Tetapi dibalik itu Pemerintah Pusat memberikan amanah pada Pemerintah Daerah agar dapat mengolah anggaran Program JKN sesuai dengan kebutuhan daerah masing-masing dengan sebaik-baiknya.

Pemerintah daerah membuat kebijakan JKN di Fasilitas Kesehatan melihat dari beberapa aspek seperti jumlah penduduk, luas wilayah dan lain sebagainya. Beberapa kebijakan Pemerintah Daerah juga dirasa terlalu rumit, sehingga tidak sedikit masyarakat bingung dan enggan untuk mengikuti kepesertaan BPJS, contohnya yaitu yang diberlakukan di Kota Surabaya.

\section{SIMPULAN DAN SARAN}

\section{Simpulan}

Regulasi kebijakan JKN pada pelayanan kesehatan primer di Puskesmas Wiyung, dari pelaksanaan pelayanan baik yang PBI maupun non PBI telah dilaksanakan sesuai dengan pedoman, sesuai dengan faskes tingkat primer. Terdapat beberapa faktor yang mempengaruhi pelaksanaan JKN pada pelayanan kesehatan primer di Puskesmas Wiyung yang meliputi faktor internal, eksternal dan lingkungan. Faktor internal meliputi kelayakan sistem pembiayaan dan pembayaran masih kurang. Faktor eksternal yaitu BPJS kurang memberi sosialisasi kepada masyarakat yang akan menjadi peserta baru. Faktor lingkungan yaitu koordinasi antara pihak Puskesmas dengan Rumah Sakit masih sangat kurang.

Implementasi Program JKN berdasarkan aspek akseptabilitas: pengembangan kebijakan JKN tidak dapat dilakukan karena semua prosedur dan pembiayaan sudah diatur sedemikian rupa oleh pembuat kebijakan. Kemudian aspek adopsi: Puskesmas Wiyung selalu menyesuaikan semua prosedur pelayanan terkait JKN dengan peraturan yang ada, karena memang tidak boleh menyimpang dari kebijakan yang telah ditentukan. Aspek ketepatan: program JKN di Puskesmas Wiyung telah sesuai dengan tujuan penyelenggaraan JKN yang terdapat dalam UU No. 40 Tahun 2004 Pasal 19 ayat 2. Aspek kelayakan: program JKN di Puskesmas Wiyung masih kurang begitu baik, tepatnya pada sistem pembiayaan dan pembayaran. Aspek kepatuhan: Puskesmas Wiyung menjalankan Program JKN sesuai dengan kebijakan yang diberikan oleh Pemerintah. 
Terkait kepesertaan BPJS, tidak semua pengunjung Puskesmas Wiyung telah menjadi peserta BPJS. Pasalnya sistem administrasi dianggap terlalu rumit untuk dipahami dengan mudah oleh masyarakat. Pemerintah Daerah juga perlu memperhatikan beberapa aspek seperti jumlah penduduk, luas wilayah dan lain sebagainya dalam membuat kebijakan JKN di Fasilitas Kesehatan. Beberapa kebijakan dirasa terlalu rumit, sehingga tidak sedikit masyarakat bingung dan enggan untuk mengikuti kepesertaan BPJS.

\section{Saran}

Saran untuk perbaikan pelaksanaan kebijakan JKN di Puskesmas Wiyung adalah sebagai berikut :

a. Penguatan manajemen Puskesmas Wiyung dalam mengakomodir terlaksananya program JKN.

b. Penguatan koordinasi dengan pihak BPJS apabila ada keterlambatan pembayaran kapitasi, dan masalah anggota kepesertaan pasien BPJS.

c. Penguatan koordinasi dengan pihak Rumah Sakit rujukan bila memang ada miskomunikasi atau masalah lain yang terkait penerimaan pasien rujukan di Rumah Sakit yang dituju.

d. Penguatan pemberian edukasi kepada masyarakat/pasien bahwa Puskesmas mampu memberikan pelayanan terbaik ketika pasien tidak perlu dirujuk ke Rumah Sakit.

\section{REFERENSI}

Depkes RI. (2004). Undang-Undang Nomor 40 Tahun 2004 Tentang Sistem Jaminan Sosial Nasional.

Kemenkes, RI. (2014). Peraturan Menteri Kesehatan Republik Indonesia Nomor 19 Tahun 2014 tentang Penggunaan Dana Kapitasi Jaminan Kesehatan Nasional Untuk Jasa Pelayanan Kesehatan dan Dukungan Biaya Operasional pada Fasilitas Kesehatan Tingkat Pertama Milik Pemerintah Daerah.

Kemenkes, RI. (2014). Peraturan Menteri Kesehatan Republik Indonesia Nomor 28 Tahun 2014 tentang Pedoman Pelaksanaan Program Jaminan Kesehatan Nasional.

Kemenkes, RI. (2014). Peraturan Menteri Kesehatan Republik Indonesia Nomor 75 Tahun 2014 tentang Pusat Kesehatan Masyarakat.

Khariza, HA. (2015). Program Jaminan Kesehatan Nasional: Studi Deskriptif Tentang FaktorFaktor Yang Dapat Mempengaruhi Keberhasilan Implementasi Program Jaminan Kesehatan Nasional Di Rumah Sakit Jiwa Menur Surabaya. 3(1): 1-7

Sugiyono. (2011). Metode Penelitian Kuantitatif Kualitatif dan $R \& D$. Bandung: Alfabeta.

Widodo, Joko. (2013). Analisis Kebijakan Publik:Teori, Proses, dan Studi Kasus. Yogyakarta: CAPS 